\title{
Propos d'amour, de religion, de politique et de littérature. La correspondance entre Louis Veuillot et la comtesse Juliette de Robersart (1862-1869), Texte établi, présenté et annoté par Roland Mortier
}

Ida Merello

\section{OpenEdition}

\section{Journals}

Édition électronique

URL : https://journals.openedition.org/studifrancesi/46142

DOI : 10.4000/studifrancesi.46142

ISSN : 2421-5856

Éditeur

Rosenberg \& Sellier

Édition imprimée

Date de publication : 1 octobre 2007

Pagination : 469

ISSN : 0039-2944

Référence électronique

Ida Merello, « Propos d'amour, de religion, de politique et de littérature. La correspondance entre Louis Veuillot et la comtesse Juliette de Robersart (1862-1869), Texte établi, présenté et annoté par Roland Mortier », Studi Francesi [En ligne], 152 (LI | II) | 2007, mis en ligne le 30 novembre 2015, consulté le 24 novembre 2021. URL : http://journals.openedition.org/studifrancesi/46142 ; DOI : https://doi.org/ 10.4000/studifrancesi.46142

Ce document a été généré automatiquement le 24 novembre 2021.

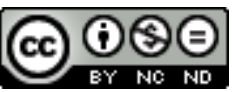

Studi Francesi è distribuita con Licenza Creative Commons Attribuzione - Non commerciale - Non opere derivate 4.0 Internazionale. 
Propos d'amour, de religion, de politique et de littérature. $\mathrm{La}$ correspondance entre Louis Veuillot et la comtesse Juliette de Robersart (1862-1869), Texte établi, présenté et annoté par Roland Mortier Ida Merello 


\section{RÉFÉRENCE}

Propos d'amour, de religion, de politique et de littérature. La correspondance entre Louis Veuillot et la comtesse Juliette de Robersart (1862-1869), Texte établi, présenté et annoté par Roland MORTIER, pp. 440.

1 Morder raccoglie qui un corpus imponente delle lettere che si scambiarono lo scrittore ultra cattolico Louis Veuillot e l'aristocratica belga Juliette de Robersart, cattolica tradizionalista a sua volta, ma attiva invece sul piano mondano. L'indice dei nomi di questa corrispondenza cita, tra gli altri, quelli di Ampère e di Mme Aupick, di Baudelaire, Constant, Lamartine, Nadar, Sainte-Beuve e Stendhal. Come dire che se anche gli autori dell'epistolario non sono certo di primo piano nella storia letteraria, la loro corrispondenza può avere interesse per tutti gli studiosi. Citiamo come esempio le riflessioni di Mme de Robersart su Stendhal, che ci mostrano quale poteva essere l'atteggiamento di lettura dei suoi contemporanei, oppure il suo resoconto del funerale di Baudelaire; mentre dobbiamo a Veuillot alcune gustose considerazioni sull'Hernani di Hugo. 